\title{
線形計画法を用いた散歩経路における道路特性評価値の解析
}

\section{Evaluation of Road Characteristics in Walking Routes using Linear Programming}

\author{
外井哲志 ${ }^{*}$ ・坂本紘二*2 \\ Satoshi TOI, Koji SAKAMOTO
}

\section{1.はじめに}

これからの成熟社会においては、交通としての歩行は もとより、心身の健康維持のための歩行や散策の重要性 が高まることが予想される。そうした社会では、安全で 楽に歩けるだけでなく、気持ちよく歩ける歩行空間を 質・量ともに充実することが要請されるものと思われる。 さらに、魅力ある歩行空間の整備は、沈滞した商店街を 活性化する効果も期待できる。このように、歩行空間の 整備はより良い生活環境づくり・まちづくりにおいて重 要な役割を担っているといえる。

こうした背景から、著者らは「散歩」を通して望まし い歩行空間のあり方を探ることを目的とした研究を継続 しており、その一環として、福岡県浮羽郡田主丸町にお いて散歩行動調査を実施し、その調查結果の分析から、 次のような手順で散歩行動の全体像を明らかにしてきた。

すなわち、散歩行動に関する意識デー夕に基づいて散 歩行動を 12 の行動分類にパターン化し 1、次に、散歩経 路の分析から散歩者が選好する道路特性を明らかにする とともに 2)、散歩経路の利用構造と形態との関係を明ら かにした 3)。

これら一連の分析からは、研究例が少ない散歩行動に 関して多くの知見を得ることができたものの、現在の研 究段階としては現象の説明に止まっており、必ずしも歩 行空間の量的計画に利用できる散歩行動の予測モデルの 構築にはいたっていない。

そこで今回、著者らは、散歩経路の予測モデルの構築 を目標とし、線形計画法を用いて、散歩経路の快適性の 観点から、散歩経路上の各道路特性に定量的な評価值を 求める試みを行った。本稿では、分析対象経路の設定方 法、数理モデルの定式化の考え方を述べた後、これを前 述の調查デー夕に適用して、道路特性の評価値を求めた うえで、その解釈と適用可能性について検討を加えたも のである。

\section{2. 分析対象経路の設定}

キーワード：地区交通計画、歩行者交通計画、歩行者交通行動 * 1 : 正会員、九州大学大学院工学研究科、干812-8581 福岡市東 区箱崎 1-10-6,Tel092(642)3277, Fax092(642)3306、* 2 : 正会 員、下関市立大学、Tel 0832(54)8652、
（1）調査デー夕の概要

平成 6 年 10 月、福岡県浮羽郡田主丸町において散歩行 動調查を実施した。同町は福岡県南部の田園地帯に位置 し、人口は約 22,000 人であるが、近年、人口の自然減と ともに高齢化が進みつつある。

調查の項目は、個人属性、散歩行動意識調查（頻度、 目的、時刻、時間など）と経路調査（地図に記入）から 構成されている。町の中心部に居住する中学生以上の住 民 1130 人を調查対象とし、訪問留置、訪問回収方式で 814 の有効回答票を回収した。このうち、散歩行動意識 分析に使用可能なもの 367 票、散歩経路分析に使用可能 なもの 319 票であった。

このほか、同地区の道路網デー夕を作成し、各リンクの 道路状況(舗装、線形、沿道状況、交通状況など)調查を実 施した。以下では、上述の散歩経路データと道路状況デ 一夕に基づいて分析を進めている。

（2）可能路導入の必要性

散歩経路に選ばれやすい道路特性の評価値を求めるに あたり、次の 2 種類の経路を考える。

第一は「実経路」である。これは、現実に散歩者によ って選ばれた経路であり、散歩行動調查において地図上 に記入された経路をリンク単位に変換したものを分析デ 一タとして用いる。

第二は「可能路」である。これは、害経路と同じ起点(終 点)、実経路とほぼ同じ延長を持つ経路で、実経路とあま り変わらない時間で歩行できると考えられる仮想の経路 である。可能路は、調査等で入手することが困難である ので、対象地域の道路網デー夕にもとづき、後述の方法 によってランダムに探索して求める。本研究では、この 可能路を実経路との比較対照に用いる。

以下、この可能路を導入する必要性について述べる。

実経路は、利用された経路の実態であることから、散 歩者の道路特性評価性向の実態を反映しているものと考 えられる。しかし、散歩経路の選択は、それぞれの散歩 者の居住地の道路特性に大きく左右されるため、各散歩 者が最も好ましいと思う道路特性を常に選択できるとは 限らない。したがって、その散歩者にとって、実経路に 含まれる道路特性のすべてが散歩経路の道路特性として 好ましいわけではなく、各散歩者は自宅周辺の道路環境 
の中から相対的に好ましいと感じる道路特性を選び取っ ていると考えられる。このような理由から、自宅周辺の 道路特性の平均的な像を表現するために、可能路を抽出 し、これと実経路を比較することが必要となる。

さらに、実経路のみに基づいた分析では、その結果に 次のような偏りが生じる危険性がある。

その第一は、散歩者の居住地の偏在である。調査対象 者の多くが中心市街地に居住しているため、データとし て得られた散歩経路が市街地内の道路に偏りがちになり、 そのため分析結果において、市街地の道路特性が各散歩 者個人の実際の評価よりも過大に評価されてしまう危険 がある。第二は、散歩経路選択の居住地による制約であ る。散歩経路には、散歩者の好みに関わらず必ず始点・ 終点近傍の道路が含まれるため、分析結果において、居 住地周辺の道路特性が散歩者の評価よりも過大に評価さ れる危険性がある。

可能路は、散歩者がその居住地を起点として、一定距 離の範囲内で歩くことが可能な経路であり、その集合体 の道路特性は、居住地を中心としてランダムに歩き回っ た場合の平均的な道路特性を示すと考えることができる。 さらに、居住地に近い道路ほど高い割合で可能路に含ま れることから、そうした道路の特性が色濃く反映される 仕組になっている。

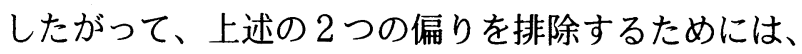
実経路から得られる特性を、可能路の平均的特性のスク リーンにかけ、そのうえで残存した特性を散歩者が選ん だ特性であると考えるのが合理的である。

\section{（3）可能路の求め方}

可能路は次の手順で求めることができる(図-1 参照)。 (1)起点 $\left(\mathrm{k}_{0}\right.$ : 散歩者の居住地) を設定し、起点に接続す るリンク群から、一様乱数を用いてランタムに 1 本のリ ンク $\left(\mathrm{A}_{0}\right)$ を選定する。

(2) $\mathrm{A}_{0}$ の他端（$\left(\mathrm{k}_{1}\right)$ に接続するリンク群 $\left(\mathrm{A}_{0}\right.$ を含む $)$ よ り、一様乱数を用いてランダムに 1 本のリンク $\left(\mathrm{A}_{1}\right)$ を 選定する。

(3) $\mathrm{A}_{1}$ の他端 $\left(\mathrm{k}_{2}\right)$ が $\mathrm{k}_{0}$ に等しい場合には、経路 $\mathrm{k}_{0} \rightarrow \mathrm{k}$ ${ }_{1} \rightarrow \mathrm{k}_{2}\left(\mathrm{k}_{0}\right)$ の経路長と実経路長との差が実経路長の

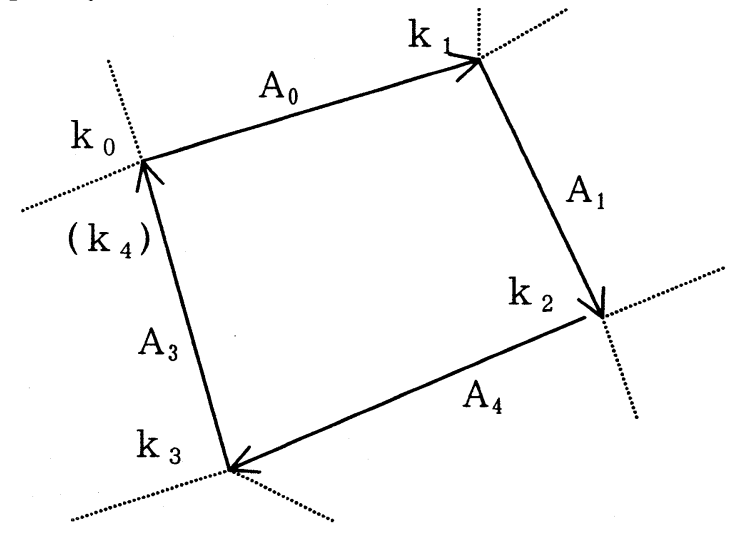

図-1 可能路探索の手順 $\pm 10 \%$ 以内（実経路とほぼ等しいと考えられる範囲）で あれば、経路 $\mathrm{k}_{0} \rightarrow \mathrm{k}_{1} \rightarrow \mathrm{k}_{2}\left(\mathrm{k}_{0}\right)$ を可能路とする。上記 の差が+10\%以上の場合には、この経路を棄却し(1)へも どる。-10\%以下の場合には、(2)に準じた作業を継続する。

一般には、1 経路中で同じリンクを複数回通過する場 合が考えられるので、実経路のデー夕から 1 経路中で同 一リンクを通過する回数を集計した。その結果、1 回が $76.5 \% 、 2$ 回が $23.4 \% 、 3$ 回が $0.1 \% 、 4$ 回以上は皆無 であり、同一リンクを往復することはあっても、3 回以 上通過することは極めて少ないことがわかった。そこで、 上記の手順中において、すでに 2 回利用されているリン クは、選択対象から除外することとした。

\section{3.線形計画法を用いた解析モデル}

\section{（1）解析方法}

本研究で用いる散歩経路は、選択された環境条件が 各々異なっている。このため、この点を考慮せずに、319 本の全経路を統計的に分析することは無意味である。ま た、各散歩者の居住地が離散しており、散歩経路に重な りが少ないため、ある散歩者の経路が他の散歩者の経路 として選定される可能性は皆無である。すなわち、本研 究の経路デー夕は、共通の選択肢がないという構造のた め、非集計ロジットモデルなどの一般的な経路選択モデ ルの適用は不可能である。

そこで本研究では、個々の散歩経路単位で選好特性を 分析する必要があること、さらに可能路群を比較対照し て居住地の特性の偏りを排除する必要性があることを同 時に考慮し、これらの条件を満たす手法として、線形計 画法を用いた以下の解析法を考案したものである。

\section{（2）経路選択の仮定}

散歩行動調查では、散歩者 1 人につき 1 本の散歩経路 を調査をしており、本研究ではこれを基本とする。すな わち、個々の散歩者は、自宅周辺にある数多くの散歩経 路の中から、自分の好みに合う経路を選びだしており、 それが散歩経路データで示されていると考える。

ここで、各散歩者が選択対象とするのは、出発点を散 歩者の自宅とし、実際の散歩経路とほぼ同じ距離を持つ 経路である。こうした散歩経路 (可能路)を多数探索し、 これらと実経路との道路特性上の相違に基づいて解析を 行う。このため、次のような仮定をおくことにする。 (1)散歩者にとって、実際に散歩する経路（実経路）は、 どの可能路よりも魅力的である。

(2)散歩者は、自宅周辺の道路状況を熟知している。 (3)経路全体の魅力は、散歩経路を構成する個々の道路区 間の道路特性の評価値の和で表される。

(4)散歩の出発点が変わっても、同一地域内であれば同の評価基準で行動する。

(5)道路特性の評価は、散歩者（グループ）によって異な 
るが、状況によってその評価が大きくは変化すること はない。

仮定(1)(2)は、経路調査デー夕を利用して評価值を求め るための前提であり、(3は総合評価の方法に関する仮定、 (4)(5)は、解析結果を利用する立場からの仮定である。

\section{（3）線形計画問題の定式化}

散歩経路の道路特性 $\mathrm{i}$ カテゴリー $\mathrm{j}$ (例えば、道路特性 $\mathrm{i}$ : 舗装、カテゴリー $\mathrm{j}$ : アスファルト、・..など。以降、 カテゴリー $\mathrm{ij}$ と呼ぶ) の延長を $\mathrm{l}_{\mathrm{ij}} \mathrm{r}$ 、散歩者がカテゴリー ij の単位延長に対してもつ効用の值を $a_{i j}$ とする。

このとき、仮定(3に基づけば、実経路 $\mathbf{r}$ を散歩すると きの効用は次式で表される。

$$
\mathrm{V}_{\mathrm{r}}=\sum_{\mathrm{i}} \sum_{\mathrm{j}(\mathrm{i})} \mathrm{a}_{\mathrm{ij}} \mathrm{l}_{\mathrm{ij}}^{\mathrm{r}}
$$

ここで、実経路 $\mathrm{r}$ と起点を同じくし、ほぼ同延長をも つ経路（可能路）を $\mathrm{k}$ とすると、経路 $\mathrm{k}$ を利用する場合 の散歩者の効用は、次のように表わせる。

$$
\mathrm{V}_{\mathrm{k}}=\sum_{\mathrm{i}} \sum_{j(\mathrm{i})} \mathrm{a}_{\mathrm{ij}} \mathrm{l}_{\mathrm{ij}} \mathrm{k}^{\mathrm{k}},
$$

散歩者にとって、実際に利用された散歩経路はそうで ない経路よりも効用が高いと考えられる(仮定(1))。すな わち、すべての経路 $\mathrm{k} に つ い て ~ V_{\mathrm{r}} \geq \mathrm{V}_{\mathrm{k}}$ であるから、

$$
\left.\sum_{\mathrm{i}} \sum_{\mathrm{j}(\mathrm{i})} \mathrm{a}_{\mathrm{ij}}\left(1_{\mathrm{ij}} \mathrm{r}-1_{\mathrm{ij}} \mathrm{k}\right) \geq 0 \quad \text { (for all } \mathrm{k}\right)
$$

となる。

ここで、各道路特性は道路の舗装や幅員などの相互に 異なる内容をもつ特性であり、一方、カテゴリーはそれ ぞれの道路特性内で相互補完関係にあることから、道路 特性内でのカテゴリ一評価値の総和は 0 でなければなら ないと考え、次の制約条件を導入する。

$$
\sum_{j(i)} a_{i j}=0 \quad \text { (for all i) }
$$

これを 1 本の実経路における道路特性評価値の決定に 関する最適化問題の形で表現すると、つぎのようになる。

$$
\begin{aligned}
& \text { Maximize } \mathrm{V}_{\mathrm{r}}=\sum_{\mathrm{i}} \sum_{\mathrm{j}(\mathrm{i})} \mathrm{l}_{\mathrm{ij}} \mathrm{r} \mathrm{a}_{\mathrm{ij}} \text {, } \\
& \text { s.t. } \left.\quad \sum_{\mathrm{i}} \sum_{j(\mathrm{i})}\left(\mathrm{l}_{\mathrm{ij}}^{\mathrm{r}} \mathrm{l}_{\mathrm{ij}} \mathrm{k}\right) \mathrm{a}_{\mathrm{ij}} \geq 0 \quad \text { (for all } \mathrm{k}\right) \text {, } \\
& \left.\sum_{j(i)} a_{i j}=0 \quad \text { (for all } i\right),
\end{aligned}
$$

and each $a_{i j}$ is not non-negative.

上式において、 $a_{\mathrm{ij}}$ は非負条件に拘束されないので、2 つの非負の変数 $a_{i j}{ }^{\prime}(\geq 0)$ と $a_{0}(\geq 0)$ を導入する。

$$
a_{i j}=a_{i j}{ }^{\prime} a_{0}
$$

\begin{tabular}{|c|c|c|c|}
\hline \multicolumn{2}{|c|}{ Maximize } & $V_{r}=\sum_{i} \sum_{j(i)} l_{i j}{ }^{r} a_{i j}{ }^{\prime}-L_{r} a_{0}$, & \\
\hline s.t. & $\sum \sum_{i j(i)}$ & $\Delta \mathrm{l}_{\mathrm{ij}} \mathrm{k}^{\mathrm{a}} \mathrm{a}^{\prime} \geq \Delta \mathrm{L}_{\mathrm{k}} \mathrm{a}_{0} \quad($ for all $\mathrm{k})$ & (9) \\
\hline & $\sum_{j\left({ }_{(i)}\right.} a_{i j^{\prime}}=$ & (for all i), & \\
\hline
\end{tabular}

さらに、

$$
\begin{aligned}
& \sum_{\mathrm{i}} \sum_{\mathrm{j}(\mathrm{i})} \mathrm{l}_{\mathrm{ij}} \mathrm{k}=\mathrm{L}_{\mathrm{k}}, \quad \sum_{\mathrm{i}} \sum_{\mathrm{j}(\mathrm{i})} \mathrm{l}_{\mathrm{ij}}^{\mathrm{r}}=\mathrm{L}_{\mathrm{r}} \\
& \Delta \mathrm{l}_{\mathrm{ij}}^{\mathrm{k}}=\mathrm{l}_{\mathrm{ij}}^{\mathrm{r}-\mathrm{l}_{\mathrm{ij}} \mathrm{k} 、} \quad \Delta \mathrm{L}_{\mathrm{k}}=\mathrm{L}_{\mathrm{r}}-\mathrm{L}_{\mathrm{k}}
\end{aligned}
$$

とすれば、式 (5) の最適化問題は次のように書き換え ることができる。

\section{（4）解析上の問題点と対応策}

上記問題を解くに当たって、いくつかの問題点が考え られる。以下にその問題点と対応策を述べる。 (1)条件式右辺の $\mathrm{a}_{0}$ は決定変数であるので、条件式は $\sum \sum$ $\Delta \mathrm{l}_{\mathrm{ij}} \mathrm{k}^{\mathrm{aij}} \mathrm{a}^{\prime}-\Delta \mathrm{L}_{\mathrm{k}} \mathrm{a} \mathrm{a} \geq 0$ が本来の形であるが、このままでは右 辺の定数項が 0 であるため、可能解がえられない。そこ で $\mathrm{a} 0$ を定数とみなし、数值を与えて解析する。したがっ て、他の決定変数は絶対値としての意味を持たず、相対 的な大小関係のみが問題となる。

(2)能路 $\mathrm{k}$ が実経路 $\mathrm{r}$ と同じ長さを持つ場合には、 $\Delta \mathrm{L}_{\mathrm{k}}=0$ となってしまうため、(1)と同様の問題点が生じるが、こ の場合には $\mathrm{a}_{0}$ を定数とみなす対応も無意味である。した がって、このような制約条件式は除外する。

(3)可能路 $\mathrm{k}$ をランダムに求めると互いに全く同一のもの が得られ、制約条件式巾に同一の式が存在する。この場 合には、同一の制約条件式を 1 個に限定する。

(4)地域によっては、ある種の道路特性が一様で特定の力 テゴリーに偏っているため、散歩経路の選び方とは無関 係に $1_{\mathrm{ij}} \mathrm{k}$ の值が同じ組合せをとる(すべての制約条件式に おいて、特定の変数 $a_{\mathrm{ij}}{ }^{\prime}$ の係数 $\mathrm{l}_{\mathrm{ij}} \mathrm{k}$ の值が一定となる)こ とがあり、特殊な場合には、あるカテゴリーに属する道 路が全くないこともある。この場合には、すべての制約 条件式において、変数 $a_{i j}$ の係数 $\mathrm{l}_{\mathrm{ij}} \mathrm{k}$ が 0 となる。このよ うな場合には、 $a_{i j}$ を決定変数から除外する。

\section{4. 道路特性評価値に関する分析}

\section{（1）道路特性評価値の計算}

散歩者の自宅周辺の道路網デー夕に基づき、2 . (3) に示した方法により、319 本の実経路各々に対して可能 路を多数 (100 本) 探索した。

次に、実経路と可能路の組み合せ毎に、式（9）の係 数 $\mathrm{l}_{\mathrm{ij}}{ }^{\mathrm{r}} 、 \mathrm{Lr} 、 \Delta \mathrm{l}_{\mathrm{ij}} \mathrm{k} 、 \Delta \mathrm{L}_{\mathrm{k}}$ を求め、 $\mathrm{a}_{0}=100$ として線形計 画問題を解析した。その結果として、61 組の最適解を含 む合計 265 組の可能解が得られたが、54 本の散歩経路に ついては、可能解が得られなかった。

\section{（2）解の転用範囲と解集合の説明力に関する分析}

265 組の道路特性評価値の各組は、それに基づいて計 算される実経路の評価值が、その実経路に対応するどの 可能路のそれよりも高いことを、個別に保証している。

しかし、この解の個別性は、必ずしもある実経路デー夕 から得られた道路特性評価值が、他の実経路の選択状況 
を説明し得ないことを意味しない。すなわち、265 組の 可能解は、265 組の経路を相互に説明しうるばかりでな 表-1 道路特性カテゴリ一別の評価値 $\left(\mathrm{a}_{\mathrm{iji}}\right)$

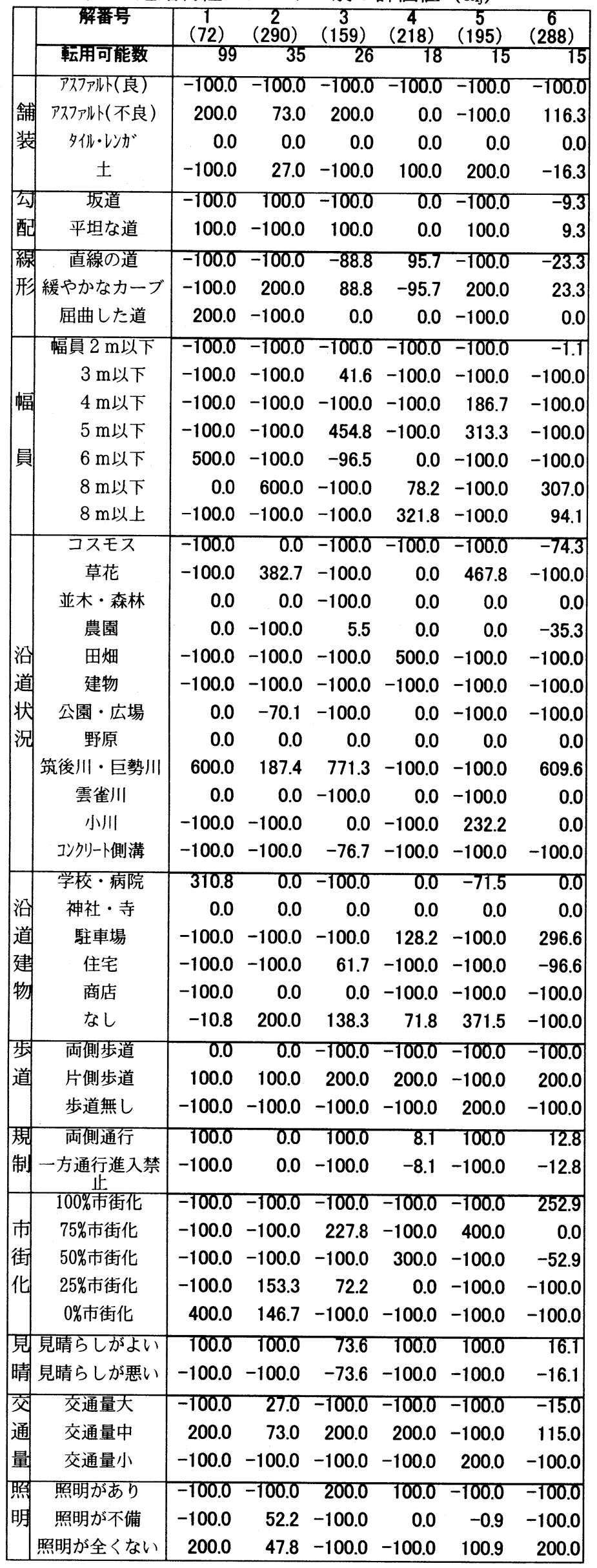

く、可能解を求め得なかった 54 本の散歩経路に対しても、 ある程度の説明力を持つと考えられる。

そこで、この点を実証するため、本研究では、265 組の 可能解の転用可能性を次の手順で分析した。

(1)265 組相互の転用可能性を調べるため、265 組の解の 各々が他の実経路に転用可能（転用可能な解とは、全制 約条件を満足する可能解をいう)であるケース数を調べ、 その結果から、265 本の実経路におけるすべての制約条 件を満足するのに必要な可能解の和集合 $\{M\}$ を求めた。こ のとき、\{M\}の要素数は 47 であった。すなわち、\{M\}に 含まれる可能解のいずれかを用いれば、265 本のどの実 経路の制約条件もすべて満足できることがわかった。

(2)可能解が得られなかった 54 組のデータへの転用可能 性を調べるため、対象を 319 組に拡張したうえで、制約 条件を緩和し（5 個までの制約条件は満たされなくても よいとした)、これに伴って変化した解の和集合 $\{\boldsymbol{M}\}$ とそ の転用可能範囲の拡大状況を調べた。その結果、 $\{\boldsymbol{M}\}$ の 要素数は 25 に減少し、\{ $\{\boldsymbol{M}\}$ の実経路番号之転用可能な 実経路数 (()内) は、

$\{72(99), 290(35), 159(26), 218(18), 195(15), 288(15), 35(12)$ ,17(12),152(10),108(10),1(9),171(8),6(8),83(8),120(7), 75

(7),146(6),227(6),277(6),116(5),73(5),4(2),33

$(2), 63(2), 214(2)\}$ となった。

\section{（3）道路特性評価内容の考察}

表-1に\{M\} のうち、転用可能範囲が広い 6 組の解につ いて、道路特性カテゴリ一別の評価値を示した。

第 1 の解は、No.72 の実経路とその周辺の可能路の道 路特性分析から導かれた解であり、他の 99 本の散歩経路 に関して、ほぼすべての制約条件が満たされ、大多数の 可能路よりも実経路のほうが評価值が高くなる。

この解では、アスファルト舗装 (不良)、平坦、屈曲し た道、5〜6m の幅、筑後川・巨勢川沿い、建物は学校・ 病院、0\%市街化（市街化されていない）、交通量は中程 度、照明は全くない、などの特徵をプラスに評価してい ることが分かる。

第 2 の解は、No.290 の実経路に関するもので、アスフ アルト (不良) や土、坂道、緩やかなカーブ、7〜 $8 \mathrm{~m}$ 幅、 沿道は草花や筑後川・巨勢川、建物なし、25\%市街化・ 0\%市街化（ほとんど市街化されていない）、交通量は中 〜大、照明はほとんどない、などの特徵をプラスに評価 している。

第 3 の解は、No.159 の実経路に関するもので、アスフ アルト(不良)、道路幅が $4 \sim 5 \mathrm{~m}$ 、筑後川・巨勢川、片側 歩道、75\%市街化、交通量が中程度、照明あり、などの 特徵をプラスに評価している。

第 4 の解は、No.218 の実経路に関するもので、土の路 面、直線で広い道路、田畑、50\%市街地等を評価してい る。

第 5 の解は、No.195 の実経路に関するもので、土の路 
面、緩やかなカーブ、3〜 $5 \mathrm{~m}$ 幅、沿道は草花と小川、沿 道に建物なし、歩道がない道路、75\%市街化、交通量が 少ない道路をプラス側に評価している。

第 6 の解は、No.288 の実経路に関するもので、7〜 8m の幅、筑後川・巨勢川、駐車場等の空き地、市街化が進 んだ道路、照明のない道路等をプラスに評価している。

次に、道路特性のカテゴリ一評価について解 1 〜解 6 を横断的に見るため、プラス評価の解が多いカテゴリー とマイナス評価が多いカテゴリーとを表-2に示した。

プラスに評価されるカテゴリーとしては、アスファル 卜 (不良)、平坦な道、緩やかなカーブ、筑後川・巨勢川、 建物なし、片側歩道、交通規制なし、見晴らしがよい、 交通量中、夜間照明なし、などがあげられる。一方、マ イナスに評価されるカテゴリーとしては、アスファルト

(良)、坂道、直線の道、幅員 $2 \mathrm{~m}$ 以下、沿道に建物（商 店）などがある、両側歩道、交通規制あり、見通しが悪 く、交通量大、などがあげられる。すなわち、平坦で緩 やかな線形の道路で、水辺があり、見晴らしがよく交通 量も程々といった内容がプラスに評価されているのに対 し、建物や人工物があって見通しが利かず、交通量が多 い道、または狭い道などの内容がマイナスに評価されて いるといえる。

表-2 道路特性評価値の傾向

\begin{tabular}{|c|c|c|}
\hline & プラス評価 & マイナス評価 \\
\hline 舖装 & アスファルト (不良) & アスファルト（良） \\
\hline 勾配 & 平坦な道 & 坂道 \\
\hline 線形 & 緩やかなカーブ & 直線の道 \\
\hline 幅員 & 一 & 2 m以下 \\
\hline 沿道状況 & 筑後川・巨勢川 & 建物、コンクリート側溝 \\
\hline 沿道建物 & 建物なし & 商店 \\
\hline 歩道幅員 & 片側歩道 & 両側歩道 \\
\hline 交通規制 & 規制なし & 一方通行・進入禁止 \\
\hline 市街化 & 一 & 一 \\
\hline 見晴らし & よい & 悪い \\
\hline 交通量 & 中 & 大 \\
\hline 夜間照明 & 全くない & - \\
\hline
\end{tabular}

以上のような解全体の平均的特性は、著者らが全デー 夕を一括して行った散歩経路の選好特性分析 ${ }^{2)}$ の結果に 示された傾向とおおむね一致している。このことから、 表-1 の解は総体として散歩経路の道路特性を評価し得て いるものと考えられる。

また、解番号が大きくなるにしたがって、市街化の程 度の高いカテゴリーをプラスと評価する明確な傾向があ り、市街化の程度という軸で各解の意味付けができる。

表・1で、舗装におけるアスファルト（良）が、6 個の 解いずれにおいてもマイナスに評価されているが、これ は舗装の程度が道路幅貝や交通量、沿道建物などの他の 特性と密接に関連しており、舗装の特性単独の評価值を 検出できるデー夕構造ではなかったためと考えられる。

このほか、表-1の舗装におけるタイル・レンガ、沿道 状況の野原、沿道建物の神社・寺のカテゴリーの評価值 がすべての解で 0 となっているが、これらのカテゴリー
の道路区間がもともと少ないため、解を求めた実経路、 およびそれらに対応する可能路中に、これらのカテゴリ 一に属する道路区間が含まれていなかったことを示すも のである。

\section{(4) 解 1 の評価値による散歩経路の再現性の検討}

表・1に示された 6 組の解のうち、転用可能性が最多で ある解 1 を用いて、319 本の各散歩経路において最も評 価值が高くなる可能路を抽出した。これらの可能解と実 経路との間で共通のリンクの延長を集計し、実経路に対 する比率を求めた。その結果、全体で $38.9 \%$ 、実経路以外 の可能路の評価が最高となった場合には $15.9 \%$ となった。 この結果から、経路の再現のためには、単独の解 1 のみ では説明力が不足しており、説明力を高めるためには複 数の解の併用がさけられないことがわかる。

例として、図-2にいくつかの経路の再現状況を示した。 経路 $\mathrm{A}$ は解 1 で再現できた実経路である。

経路 Bでは、解 2 では実経路を再現できるが、解 1 を 用いて評価した場合には実経路と部分的に重なるものの、 異なった形の可能路が選ばれている。

経路 $\mathrm{C}$ では、解 6 で実経路が得られるが、経路 $\mathrm{B}$ と同 様に実経路とは一部重なるものの、異なる形の可能路が 選ばれている。

経路 D では、転用可能性の低い 14 番目の解によって 実経路が再現されている。しかし、解 1 を用いた場合に は、経路 $\mathrm{B} 、 \mathrm{C}$ と同様に、部分的に実経路には重なるも のの、実経路とは異なる形態の可能路が選ばれている。

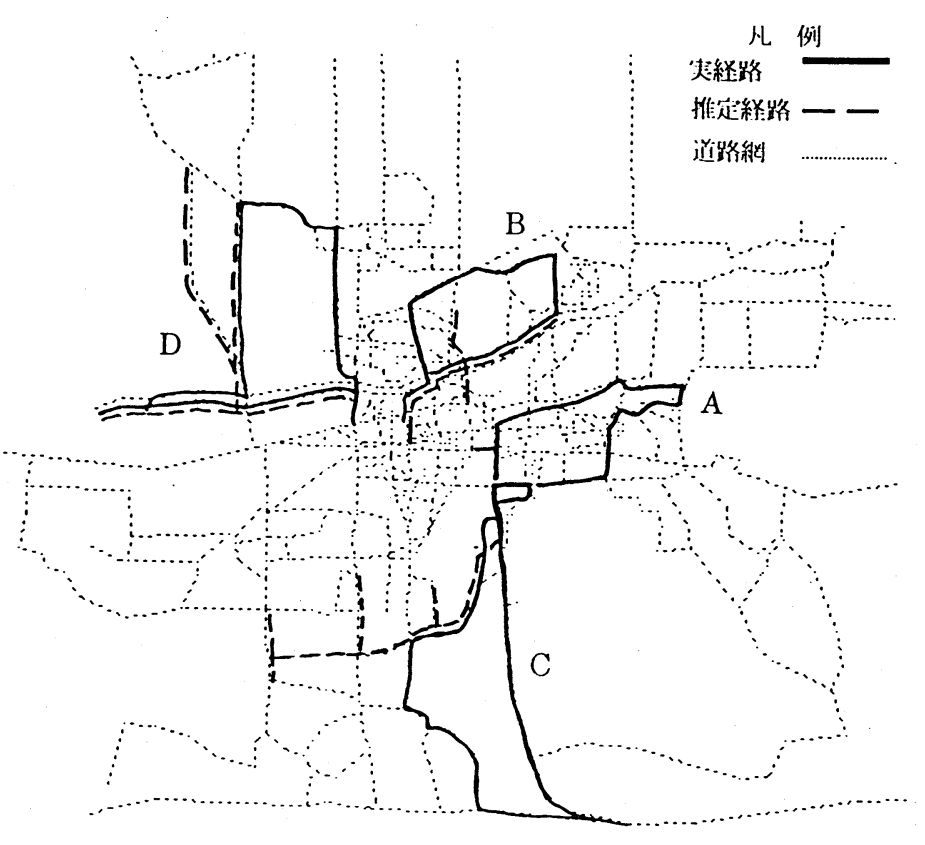

図-2 可能路から抽出された推定経路と実経路

6 ．結論と今後の課題

本研究では、散歩者にとって可能路よりも実経路が快 
適であるはずであるとの前提にもとづいて、目的関数と 制約条件式からなる線形計画問題を定式化し、これを散 歩経路の調査データに適用して、散歩者個々の道路特性 評価値を求め、その転用可能性と経路の再現性について 分析した。

その結果、線形計画モデルで求めた道路特性評価値を 用いることによって、大多数の散歩経路において、実経 路を可能路よりも高く評価することができるようになつ た。一方で、評価構造が異なる複数の解を用いることに より、全体をカバーすることはできたが、共通性の高い 少数の解を求めるには至っておらず、汎用性のある散歩 経路の予測モデルを構築することはできなかった。

その原因については、次の 3 点が考えられる。

まず、第一に、採用したデータが道路特性であり、項 目相互に関係のあるものも少なくない (例えば、舗装と幅 員と交通量など）が、線形式モデルを採用したため、こ のような特性相互の関連をモデルに取り入れることがで きなかったことが考えられる。この点に関しては、個々 の道路特性の評価值に代えて道路パターン分類の評価值 を変数として分析する方向で解決を四りたい。

第二に、可能路を求めるシミュレーションにおける経 路探索規準を、実経路の距離とリンク 1 本の最大通過回 数（2 回）の 2 項目に限定し、リンクやノードを通過す る回数の分布状況等の条件に関して、必ずしも実際の散 歩行動を反映しうる探索規準を設けなかったため、可能 路において環状路が構成される割合が少なくなるなど、
実経路とは形態が異なった可能路が出現したことが考え られる。この点に対しては、経路形態の分析を通して現 実に近い可能路を探索しうるシミュレーションモデルの 開発を試みる予定である。

第三に、モデルに個人属性をまったく取り入れていな いことがあげられる。これに対しては、多変量解析法な どを援用し、本研究で得られた評価值と個人属性との関 係を分析するところから取り組みたいと考える。

この他に、散歩経路の予測モデル構築のためには、複 数の解を統合する方法の確立が課題として残されており、 この点についても今後検討する必要があると考えている。

\section{参考文献}

1)外井、坂本、井上、中村、根本 : 散歩行動の実態とそ の類型化に関する研究、土木計画学研究・論文集 No.13、 pp.743-750、1996.8

2) 外井、坂本、井上、中村、根本 : 散歩経路の道路特性 に関する分析、土木計画学研究・論文集 No.14、 pp.791-798、1997.9

3）外井、坂本、井上、中村、根本 : 道路特性と経路の形 状要素を考慮した散歩経路の利用構造に関する研究、土 木計画学研究・論文集 No.16、pp.869-878、1999.9 4) 外井、坂本、白：都市部における散歩行動特性に関す る研究、土木計画学研究・論文集 No.16、pp.779-784、 1999.9

\section{線形計画法を用いた散歩経路における道路特性評価値の解析}

外井哲志・坂本紘二

著者らは、福岡県浮羽郡田主丸町で実施した散歩行動調查デー夕に基づいて、これまでに、散歩行動に関する意識デ 一夕に基づいた散歩行動のパターン化、散歩経路として好まれる道路特性の抽出、散歩経路の形態の分析を行い、散歩 行動の全体像を明らかにしてきた。本研究では、これらの研究に引き続いて、散歩経路の予測モデルの構筑を目標とし、 散歩経路の選択問題を散歩経路の快適性の観点から線形計画法問題として定式化した。次に、この数理問題を解くこと によって各道路特性の定量的評価值（解）を求め、複数の夕イプの解が存在することを示した。さらに、これらを用い て散歩経路の再現性の検討を行った。

\section{Evaluation of Road Characteristics in Walking Routes using Linear Programming}

Satoshi TOI, Koji SAKAMOTO

So far, we classified walking behavior, extracted road characteristics that were preferred by the walkers, and analyzed the shape of walking routes, based upon the data of walking behavior research at Tanusimaru town in Fukuoka prefecture. After these studies, we formulated the route choice problem using linear programming method from the view point of walking amenity, in order to build the choice model of walking routes. And then, we solved the mathematical problem to obtain the evaluation values of road characteristics, and several solutions were extracted as the result of analysis. Moreover, we checked the reliabilities of the evaluation value. 